It seems unlikely that a single book meeting all these needs will now be written, and a series of monographs is perhaps a better solution. An excellent start has been made by Dresner ${ }^{1}$ with a text on resonance escape. There is an urgent need for further works of the same quality on subjects such as thermal spectrum, numerical techniques and methods of solving the transport equation.

The translation of Galanin's book by J. B. Sykes is impeccable and the production is adequate. The price seems very high.

D. C. LESLIE

- Dresner, L., Resonance Absorption in Nuclear Reactors (Pergamon Press, London, 1960).

\section{MARKOV PROCESSES AND THEIR APPLICATIONS}

Elements of the Theory of Markov Processes and Their Applications

By Prof. A. T. Bharucha-Reid. (McGraw-Hill Series in Probability and Statistics.) Pp. xi +468 . (New York: McGraw-Hill Book Company, Inc.; London : McGraw-Hill Publishing Company, Ltd., 1960.) 89s.

T can be said straight away that this is a most 1 interesting work, of considerable value to those concerned with either the theory or the applications of stochastic processes.

The first third of the book covers the general theory of Markov processes. Branching and diffusion processes are treated in particular detail. Although the treatment is straightforward, and does not bring in measure-theoretic concepts, the description 'elements' errs on the side of modesty. The presentation is exact, and a number of advanced and novel topics are included. For example, there is the material on limit theorems for branching processes, which has hitherto lain rather inaccessibly in the Russian journal literature. Another welcome section is the elementary treatment of the Kolmogorov differential equations on p. 64 et seq.

The remaining part consists of a truly encyclopædic study of applications: biology (populations, epidemics, genetics), physics (cascades, counters, fission detectors, reactors), astronomy (brightness fluctuations, galaxy distribution, radiative transfer), chemistry (reaction kinetics), queues, telephone traffic, and machine servicing. There are more than 600 references in all.

The author has rendered a real service by combing the literature, particularly the journals, in so many disciplines and languages, and by presenting the results clearly, capably and concisely. One is also impressed by the international balance achieved: the work gives a faithful account of activity in America and in both Western and Eastern Europe.

The theoretical section of the book is fairly definitive and well rounded. This is understandably much less true of the applied section, which is virtually a report on what has been done in the various fields, rather than a digested and unified account. So, results are presented in detail, but rather baldly and indiscriminately. I, for one, would not criticize the anthor for this: had he done otherwise the book would never have been written. Indeed, I would be more prone to criticize him when he occasionally weakens to the encyclopædist's temptation and writes as though a subject were in a tolerably complete stato when this is scarcely the case. For example, the accounts of ecological competition and of reaction kinetics tend to give a more satisfactory picture than is justified. By its nature the book is concerned with frontier subjects, the development of which is often ragged, and just herein lies a principal value of the work.

Mr. Bharucha-Reid has succeeded in an ambitious task. I warmly recommend his book to anyone, student or research worker, at all interested in random processes.

P. Whitrue

\section{NEW EMPHASIS IN THE STUDY OF FORAMINIFERA}

Ecology and Distribution of Recent Foraminifera By Prof. Fred B. Phleger. Pp. viii + 297. (Baltimore, Md.: The Johns Hopkins Press; London: Oxford University Press, 1960.) 60s. net.

$\mathrm{B}$ ECAUSE of their abundance and wide distribution in marine sediments and in the plankton of past and present oceans, the shells of Foraminifera have proved valuable in stratigraphic studies and much taxonomic information has resulted. Following success in the dating of rocks, and to a lesser extent in foraminiferan taxonomy, many students of the group are now engaged in the field of palæoecology, or more specifically, in the reconstruction of fossil environments. Knowledge of the distribution and ecology of contemporary Foraminifera is of importance in such studies, and it is opportune that a book has now been written bringing together, for the first time, much of the available information on the subject.

Unlike so many papers reporting foraminiferan studies, this book includes a full account of the methods used by the author; he rightly points out that unsatisfactory methods of collection and subsequent treatment of sediment samples has rendered many published accounts less valuable.

Another obstacle to synthesizing the vast amount of previous work on foraminiferan distribution is the taxonomic confusion which exists in the group. This, of necessity, is avoided by the author, who relies on detailed studies, such as that carried out in the Gulf of Mexico, to illustrate his discussion. Nevertheless, it is unfortunate that space was not found for an appraisal of those aspects of foraminiferal distribution which would have clarified certain statements such as ". . . probably there are few benthonic species which are world-wide in distribution except those in the deep sea"' (p. 45). 'This calls for comment; especially in a book of this title.

Interesting accounts are given of the existence of depth zones for Foraminifera, of the various faunas characteristic of different environments, of the importance of establishing and assessing the living com. ponents of a foraminiferan sample and of the contamination of faunas by displacement and currents. The least-documented part of the book appears to be that dealing with the ecological factors affecting the depth distribution of Foraminifera. It is here that the estrangement of many students of the group from their colleagues working with other marine animals is very evident. The section on food has no reference to H. Sandon's The Food of Protozoa in which four pages are devoted to the Foraminifera. Furthermore (p. 123), there is reference to work on the effect of pressure on marine bacteria which, the reader is told, is the only specific evidence known to the writer concerning the effect of pressure on marine organisms. There are, however, other works on this subject to which the reader's attention ought to be directed. 